\title{
PAWEE GRYGIEL \\ Religijność i polityka. Aksjologiczny kontekst preferencji politycznych mieszkańców Rzeszowa
}

Jedną z pierwszych prób wyjaśnienia przyczyn zróżnicowania orientacji politycznych była koncepcja, według której w decydujący sposób na preferencje polityczne wplywa spoleczne uwarstwienie elektoratów, ich społeczno-ekonomiczny status, religijność i rodzaj miejsca zamieszkania Jej rozwinięciem stała się teoria Lipseta, zwracającego uwage na czynniki związane z poziomem wykształcenia oraz sposobem wychowania, warunkującymi sztywne i nietolerancyjne podejście do polityki, w efekcie zaś preferowanie ruchów autorytarnych oferujących szybkie i latwe rozwiązanie problemów społecznych (Lipset, 1959).

Wiele badań wskazuje na doniosła rolę jaką w kształtowaniu się postaw politycznych, sympatii partyjnych, preferencji wyborczych odgrywaja orientacje ideowe na osi lewica-prawica (Inglehart and Klingemann, 1976; Achen, 1975; Jacoby, 1995; Nie, Verba, and Petrocik 1976). Jednak ograniczenie się do tej jednej osi już na pierwszy rzut oka wydaje się zbyt upraszczać złożoną strukturę postaw politycznych (Wojtaszczyk, 1998). Większość badaczy uznaje ten podział tylko za jeden z wielu rozmaitych wymiarów wpływajacych na decyzje wyborcze, u podstaw których leżą złożone orientacje ideowe. Współcześni badacze zwracają szczególną uwagę na ideologię jako sferę nadającej ład wielości problemów politycznych (Poole i Rosenthal, 1997; Weisberg i Rusk, 1970; MacRae, 1958).

Ideologię rozumieć można jako system wartości, idei i przekonań, opartych na poglqdach na świat i życie społeczne, wyrażajqcych interesy grup społecznych i stanowiqcych dyrektywy działań zmierzajqcych do utrwalenia lub zmiany 
istniejących stosunków społeczno-politycznych (Przybylski, 1996: 123). W tym sensie stanowi ona zestaw idei dostarczających ogólnych wytycznych dla działań (Mahler, 1995), specyficzną mape pojęciowa, do której dopasowane zostać musza polityczne programy, sposoby rozwiązywania bieżących problemów, stosunek do innych partii, oczekiwania wobec preferencji wyborczych etc. (Budge, 1994).

Przeglądając rozmaite podstawy klasyfikacji idei prawicowych oraz lewicowych zauważyć można, iż koncentrują się one przede wszystkim na sferze ekonomiczno-gospodarczej. Wyraźnie widać to w znanej klasyfikacji Lijpharta (1984), według której podział ten zawiera się w czterech dychotomiach: a) państwowa vs prywatna własność środków produkcji; b) duża vs mała rola rządu w planowaniu gospodarczym; c) poparcie vs sprzeciw wobec redystrybucji dóbr (od ludzi bogatych do biednych); d) poparcie vs sprzeciw wobec rządowych programów opieki społecznej.

Nowsze badania prezentuja znacznie rozbudowany sposób ujmowania różnic między lewicą i prawicą. Volkens (1995) opierając się na analizie programów wyborczych prezentowanych w okresie powojennym w dwudziestu krajów o ustroju demokratycznym doszedł do wniosku, że podział „lewica-prawica” daje się opisać za pomoca 56 kategorii, odnoszących się do: stosunków zagranicznych (np. anty-imperializm), wolności i pojęć związanych z demokracją (np. prawa czlowieka), kategorie systemu politycznego (np. wydajność działań rządu i administracji), kategorie ekonomiczne (np. nacjonalizacja), dobrobyt i jakość życia (np. ochrona środowiska), struktury spoleczeństwa (np. mulitikulturalizm), kategorii rozmaitych grup społecznych (np. upośledzone grupy mniejszościowe). Podobny indeks, obejmujacy 13 wartości lewicowych oraz 13 wartości prawicowych przygotowali Laver i Budge (1993). Za wartości lewicowe uznali: regulację kapitalizmu, ekonomiczne planowanie, protekcjonizm, gospodarkę sterowaną, nacjonalizację, dekolonizację, niechęć do militaryzmu, pokój, internacjonalizm, demokrację, rozwój państwowej opieki społecznej, edukację, pozytywny stosunek do robotników. Wartości o charakterze prawicowym to z kolei: wolność inwestycji, niechęć do protekcjonizmu, kult wydajności, niechęć do rozwoju państwowej opieki zdrowotnej, konstytucjonalizm, akcentowanie roli skuteczności działań rządu, narodowy styl życia, wolność i prawa czlowieka do autonomii życia rodzinnego.

Również w polskich tekstach źródłowych odnaleźć można wielowymiarowe metody wyznaczania miejsca na osi prawica-centrum-lewica. B. Wojtaszczyk (1998) wyróżnia na przykład trzy tego typu płaszczyzny: aksjologiczna, ekonomiczno-społeczną oraz polityczna. Pierwsza związana jest $z$ wartościami, do jakich odwołuje się określone ugrupowania polityczne. Druga odnosi się do sto- 
sunku partii wobec ustroju gospodarczego i polityki społeczno-gospodarczej państwa. Trzecia zaś związana jest ze strategia polityczną realizowaną przez partię, preferowaną formą ustroju politycznego, etc. Stosunkowo często stosowany jest także podzial dwuwymiarowy, w którym orientacje polityczne fundowane są z jednej strony na bazie interesów, z drugiej zaś na osi wartości (Ziólkowski, 1999). Według W1. Wesolowskiego polski system partyjny opiera się na pięciu osiach, o następujących krańcach: narodowy/uniwersalistyczny, wyznaniowy/świecki, autorytarny/demokratyczny, leseferystowski interwencjonistyczny, rozliczenia z przeszłościa/przebaczenia (Wesolowski, 1995), które ostatecznie zawęzić można do trzech podstawowych: naród vs uniwersalizm, wyznaniowość vs świeckość, leseferyzm vs interwencjonizm (Wesołowski, 1999). Z kolei T. Żukowski (2003) wymienia: różne wizje gospodarki i związane z nimi interesy ekonomiczne, stosunek do Kościoła i jego społecznej nauki, ich roli w życiu publicznym, ocenę czasów PRL i stosunek do dekomunizacji, stosunek do demokracji i pluralizmu w życiu publicznym, opinie o polskich elitach, ludziach grających najważniejsze role w życiu publicznym, otwartość na nowe wartości i ochrona polskiej tożsamości (czynnik związany z integracją z UE).

W poniższym artykule stawiam sobie za cel prześledzenie związku lączącego postawy religijne $z$ szeroko pojętymi orientacjami politycznymi: orientacjami na wartości i interesy (jako podstawowymi wyznacznikami ideologii politycznej), orientacjami ideowymi na osi prawica-lewica, sympatiami partyjnymi, preferencjami wyborczymi, frekwencja wyborczą oraz preferowanymi formami aktywności politycznej. W celu odpowiedzi na postawione pytania odwołuję się do wyników badań przeprowadzonych od kwietnia do czerwca 2003 r. na reprezentatywnej próbie pełnoletnich mieszkańców Rzeszowa. W przeprowadzonym badaniu w celu uzyskania próby reprezentacyjnej zastosowano dobór warstwowy proporcjonalny, na podstawie którego z bazy PESEL Urzędu Miasta Rzeszowa ze wszystkich 23 osiedli miasta wylosowano proporcjonalne próby. W ten sposób dobrano i przebadano łącznie 650 osób. Do analizy zakwalifikowano 638 kwestionariuszy wywiadu.

\section{Centralność postawy religijnej (CPR) - narzędzie badawcze}

Przygotowane narzędzie badawcze (określane w dalszych partiach teksu jako indeks centralności postawy religijnej lub CPR) składało się z dziewięciu twierdzeń odnoszących się do roli zajmowanej przez przekonania o charakterze 


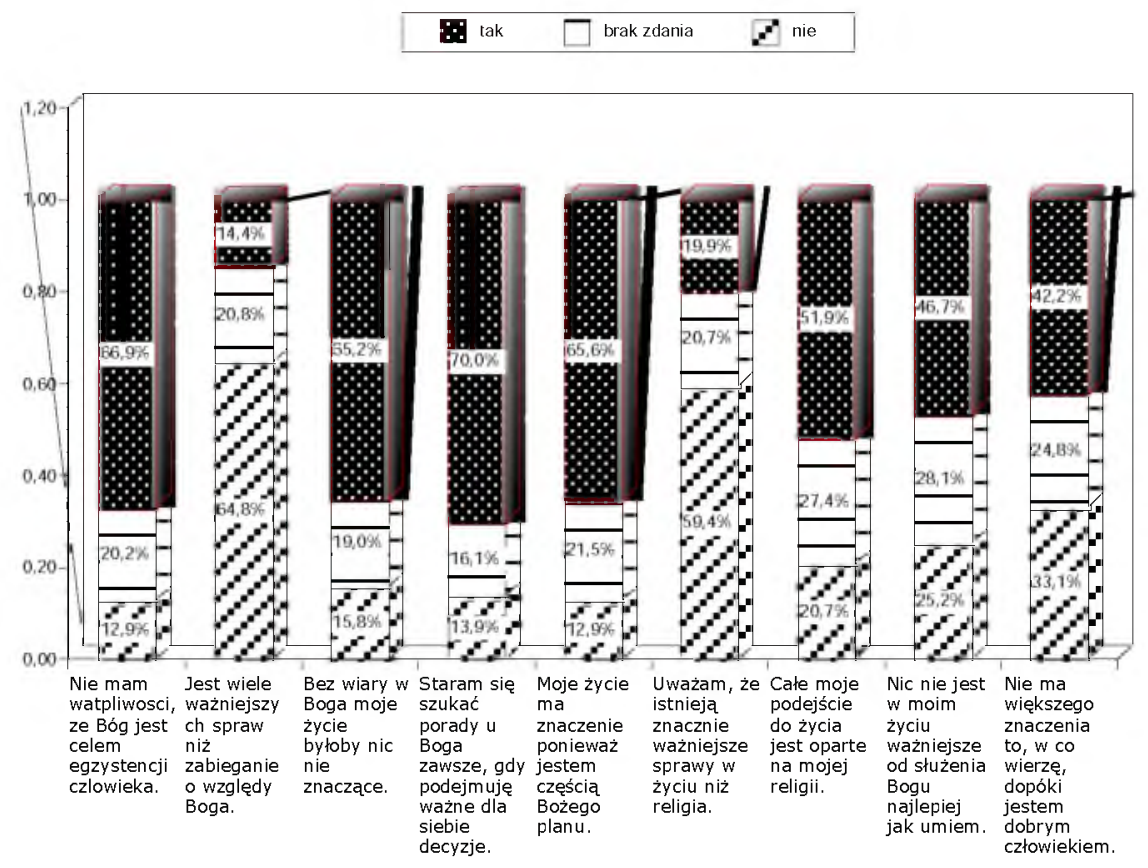

religijnym w życiu badanego. Sześć z nich miało charakter „pozytywny” (odpowiedź twierdzaca oznaczała odgrywanie przez przekonania religijne istotnej roli w świadomości badanych), trzy zaś „negatywny” (odpowiedź twierdząca świadczyła o niewielkiej roli pełnionej przez wierzenia religijne w strukturze przekonań ankietowanych). W stosunku do każdego $z$ nich badany musiał udzielić odpowiedzi w jakim stopniu z nim się zgadza, dysponując 7 . stopniową skalą: od zdecydowanie się nie zgadzam do zdecydowanie się zgadzam. Rozkład uzyskanych $w$ ten sposób odpowiedzi przedstawia Wykres 1 . Przeprowadzone badania wskazują wyraźnie, iż religijność zajmuje istotne miejsce w świadomości większości badanych, jest raczej centralnym niż peryferyjnym elementem struktury osobowej.

Weryfikując trafność teoretyczną (Hornowska, 2001 s. 95 i dalsze) utworzonego indeksu zastosowano analizę czynnikową metodą głównych składowych $^{1}$. Jak metodę wyodrębnienia odpowiedniej liczby czynników wybrano metodę wartości własnych większych niż jeden. W efekcie otrzymano - zgodnie $z$ oczekiwaniami - tylko jedna składowa, co wzmacnia założona hipotezę o homogeniczności analizowanego indeksu. Wielkość ladunków czynnikowych poszczególnych pozycji indeksu zawiera Tabela 1.

\footnotetext{
${ }^{1}$ Miara KMO wyniosła 0,924, poziom istotności testu sferyczności B a r t le t t a był niższy niż 0,001 (przy 36 stopniach swobody oraz chi kwadrat równym 4019,206).
} 
Trafność kryterialną indeksu zweryfikowano za pomocą miary skojarzeń $\eta^{2}$ (eta kwadrat) ${ }^{2}$, przyjmując za zmienne kryterialne odpowiedzi na dwa pyta-

Tabela 1. Wielkos̆ci tadunków czy nnik owych indeksu CPR

\begin{tabular}{|c|c|}
\hline & Sktadouta \\
\hline 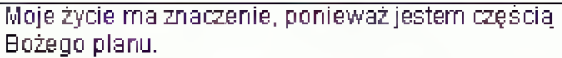 & 870 \\
\hline $\begin{array}{l}\text { Nie mam unatpliwosici, że Bóg jest celem egxystencji } \\
\text { czrowieka. }\end{array}$ & .864 \\
\hline 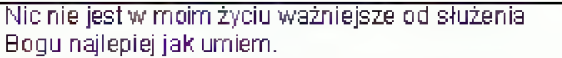 & .847 \\
\hline 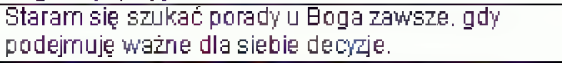 & .846 \\
\hline $\begin{array}{l}\text { Cake moje podejsie do zycia jest oparte na mojej } \\
\text { relıgi. }\end{array}$ & .037 \\
\hline $\begin{array}{l}\text { Bez wiary' Hoga moje życie bytoby nic } \\
\text { niezraczace. }\end{array}$ & .818 \\
\hline 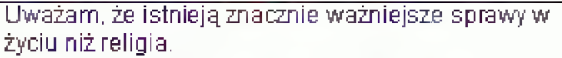 & -.717 \\
\hline $\begin{array}{l}\text { Jest wiale "ważniejszych spraw riż zabieganie a } \\
\text { wrględy' Boga. }\end{array}$ & -712 \\
\hline $\begin{array}{l}\text { Nie ma większego znaczenia to, w co wiere, } \\
\text { dopók jestem dabrym czlowiekiem. }\end{array}$ &,- 572 \\
\hline
\end{tabular}

nia związane $z$ parametrem globalnych postaw wobec wiary: o intensywność wiary religijnej oraz częstotliwość udziału w ogólnie pojętych praktykach religijnych. Zarówno w pierwszym, jak drugim przypadku wartość $\eta^{2} \quad$ wyniosła 0,395 , wskazując iż wszystkie trzy narzędzia badawcze odnoszą się generalnie do zbliżonego obszaru treściowego ${ }^{3}$.

Analizę rzetelności indeksu wykonano posługując się metodą spójności wewnętrznej $\alpha$ Cronbacha. Wspólczynnik $\alpha$ wyniós1 0,921 , co świadczy o stosunkowo wysokiej spójności wewnętrznej analizowanego narzędzia (por. Tabela 2).

\begin{tabular}{|c|c|}
\hline & $\begin{array}{l}\text { Altagdy. } \\
\text { pozycja } \\
\text { usunięta }\end{array}$ \\
\hline $\begin{array}{l}\text { Wie mam watpliwosci, że Bóg jest celerr egzystencji } \\
\text { crowileka. }\end{array}$ & .90 \\
\hline $\begin{array}{l}\text { Jest wi|e le ważniejszych spraw niżzabieganie a względy } \\
\text { Boga }\end{array}$ & 91 \\
\hline Bez wian' w Baga maje żcie bytab y nic nieznaczące. & 91 \\
\hline 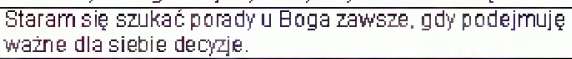 & .90 \\
\hline $\begin{array}{l}\text { Moje 亡̇ycie ma zraczenie ponieważ jestem częscia } \\
\text { Bażego planu. }\end{array}$ & .90 \\
\hline $\begin{array}{l}\text { Uważam. ̇̀e istrieja znacznie ważniejsze sprawy w Życiu } \\
\text { niż religia. }\end{array}$ & .91 \\
\hline Całe moje podejscie do z̀cia jest oparte na mojej rellnil. & 90 \\
\hline 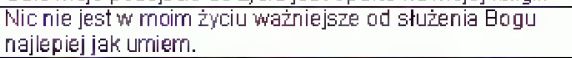 & .90 \\
\hline $\begin{array}{l}\text { Wie ma więkrego zhaczenia to, w co wienes dopóki } \\
\text { jestem dobrym crowiekiem. }\end{array}$ & .92 \\
\hline
\end{tabular}

${ }^{2}$ Eta kwadrat jest proporcją wariancji w zmiennej zależnej, wyjaśnionej różnicami między ka tegoriami zmiennej niezależnej.

${ }^{3} \mathrm{~W}$ obu przypadkach związek między zmiennymi ma charakter liniowy: im wyższa intensywność wiary, tym wyższy poziom CPR (niewierzący $[\mathrm{M}=-1,70]$, obojętni $[\mathrm{M}=-1,52]$, niezdecydowani $[M=-0,79]$, wierzący $[M=0,11]$, głęboko wierzący $[M=0,98])$ oraz im wyższa częstotliwość udziału w praktykach religijnych, tym wyższy poziom $C P R$ ( $w$ ogóle nie praktykujący $[M=-1,54]$, kilka razy w roku $[\mathrm{M}=-0,72]$, raz $\mathrm{w}$ miesiącu $[\mathrm{M}=-0,59]$, dwa, trzy razy $\mathrm{w}$ miesiącu $[\mathrm{M}=-0,21]$, $\mathrm{w}$ każdą niedzielę $[\mathrm{M}=0,23]$, w każdą niedzielę i czasami w dni powszednie $[\mathrm{M}=0,78]$ ). 


\section{Społeczno-demograficzne zróżnicowanie postaw religijnych (CPR)}

Dla sprawdzenia, które zmienne społeczno-demograficzne (oraz w jaki sposób) wpływają na badane postawy religijne zastosowano metodę wieloczynnikowej analizy wariancji (Unianova). Spośród wziętych pod uwagę zmiennych o charakterze społeczno-demograficznym ${ }^{4}$ tylko dwie w sposób statystycznie

Tabela 3. Wotyw zmienrych spatecuno-demagraficzilych na CPR

\begin{tabular}{|c|c|c|c|}
\hline Zródlo zmien nosoj & $F$ & Istotnosí & $\begin{array}{l}\text { Czastkowe } \\
\text { Eta kwadrat }\end{array}$ \\
\hline Model skory'gowarly & 3,337 & .000 & .116 \\
\hline Stata & 961 & 689 & 000 \\
\hline plect & 13.944 & 000 & .022 \\
\hline wiek & .655 & .580 & 0003 \\
\hline Whkstatcenie & .850 & 509 & .007 \\
\hline $\begin{array}{l}\text { pochodzenie } \\
\text { spotecze }\end{array}$ & 5,603 & .0100 & .035 \\
\hline $\begin{array}{l}\text { struktura spoteczno- } \\
\text { Lawodowa }\end{array}$ & 1.398 & .203 & .016 \\
\hline satysfakcja materialna & 1.813 & .125 & .012 \\
\hline
\end{tabular}

istotny oddzialywały na poziom centralności postawy religijnej: płeć oraz pochodzenie spoleczne (por. Tabela 3) ${ }^{5}$.

Analiza średnich wskazuje, iż to raczej kobiety $(\mathrm{M}=0,15)$ niż mężczyźni $(\mathrm{M}=-0,15)$ charakteryzują się bardziej centralną postawa religijna (por. Wykres 1). Jednocześnie wyraźnie wyższy poziom CPR odnotowano w przy-

padku osób pochodzących $\mathrm{z}$ rodzin chłopskich $(\mathrm{M}=0,53)$ i chłopsko-robotniczych $(\mathrm{M}=0,20)$ niż wśród ankietowanych wywodzacych się $\mathrm{z}$ rodzin robotniczych $(M=-0,07)$, rzemieślniczych $(M=-0,09)$, czy inteligenckich $(M=-0,22)$.

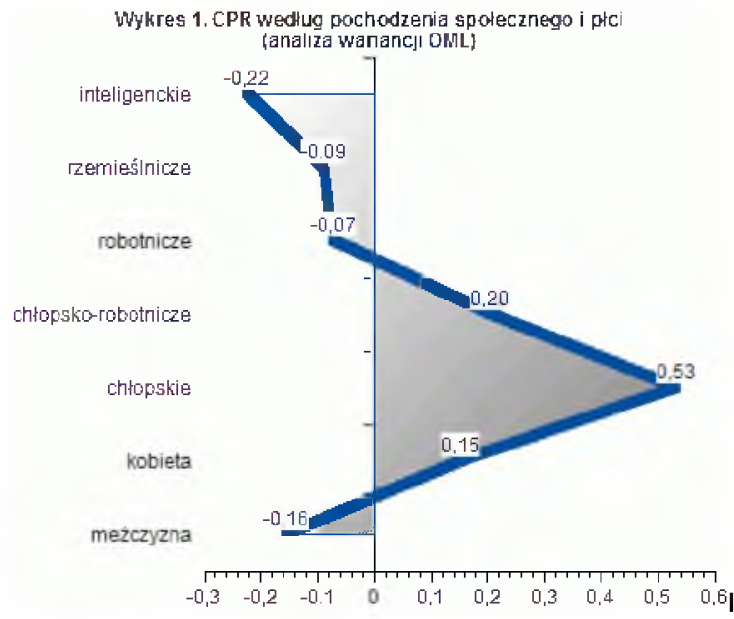

Czastkowe $\eta^{2}$ wskazuje, iż większy wpływ na CPR posiada pochodzenie spoleczne ankietowanego niż jego pleć. Podobne zależności uchwycono stosując analize drzew klasyfikacyjnych (por. Wykres 2). Czynnikiem w sposób zasadniczy różnicującym poziom CPR ponownie okazuje się pochodzenie społeczne badanego (najwyższy wskaźnik CPR odnotowano wśród badanych pochodzących $\mathrm{z}$ rodzin chłopskich, nieco niższy wśród osób z rodzin chłopsko-robotni-

czych, najniższy zaś wśród ankietowanych wychowywanych w rodzinach robot-

\footnotetext{
${ }^{4}$ Były to: płeć, wiek, wykształcenie, pochodzenie społeczne, pozycja zajmowana w strukturze społeczno-zawodowej oraz satysfakcja materialna.

${ }^{5}$ Wszystkie zmienne społeczno-demograficzne wyjaśniały jedynie nieco ponad $11 \%$ wariancji zmiennej niezależnej.
} 
niczych, rzemieślniczych oraz inteligenckich). Drugim statystycznie istotnym czynnikiem różnicujacym CPR jest płeć, przy czym jej wplyw uwidacznia się przede wszystkim wśród osób pochodzących z rodzin robotniczych, rzemieślniczych i inteligenckich. Wśród ankietowanych wywodzących się z ww. środowisk wyraźnie wyższy poziom CPR prezentują kobiety niż mężczyźni ${ }^{6}$. Płeć nie różnicuje centralności postawy religijnej wśród osób wywodzących się z rodzin chłopsko-robotniczych oraz chłopskich.

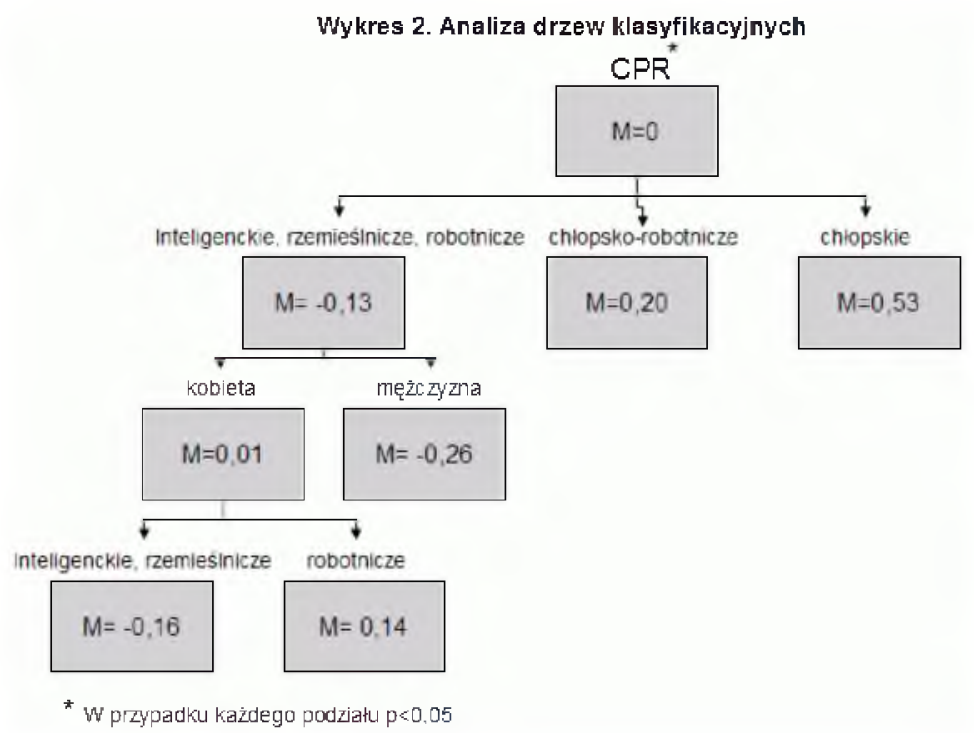

\section{CPR a system wartości społecznych}

W celu uchwycenia specyficznych wartości i postaw, które charakteryzować mogły sympatyków różnych opcji ideowych posłużono się kilkuset pytaniami wchodzących w skład 17 indeksów, dotyczących zarówno sfery wartości spolecznych, jak moralnych, stricte politycznych, czy gospodarczych ${ }^{7}$. Ze względu

${ }^{6}$ Przy czym kobiety pochodzące z rodzin robotniczych prezentują wyższy poziom CPR niż pochodzące $z$ rodzin inteligenckich czy rzemieślniczych.

${ }^{7}$ Posłużono się indeksami mierzącymi: patriotyzm, etnocentryzm, socjocentryzm, cynizm, punitywizm, autorytaryzm, uległość, tradycjonalizm moralny, tradycjonalizm seksualny, negatywna ocenę natury człowieka, polityczną bezsilność, polityczne wyobcowanie, niechęć do kapitału zagranicznego, socjalistyczny resentyment, interwencjonizm spoleczno-gospodarczy, akceptację zróżnicowania społecznego, akceptację prywatyzacji. Każdy z indeksów sprawdzany był pod względem rzetelności (wewnętrznej spójności) za pomocą współczynnika alfa Cronbacha oraz trafności treściowej przy zastosowaniu analizy czynnikowej. Niestety brak wystarczającej ilości 
na znaczną liczbę wykorzystanych indeksów mierzący orientacje ideowe postawiono dokonać ich pogrupowania w homogeniczne grupy. Do tego celu wykorzystano analizę czynnikową metodą głównych składowych z rotacją Oblimin. Jako metodę określenia ilości niezbędnych do wyodrębnienia składowych posłużono się standardową metoda wartości własnych większych od 1 . W rezultacie wyodrębniono cztery składowe glówne (por. Tabela 4). Pierwsza odnosi się zasadniczo do negatywnej percepcji rzeczywistości spolecznej. Druga związana jest konserwatyzmem moralnym oraz przywiazzaniem do wartości narodowych. W skład trzeciego czynnika weszly indeksy dotyczace poglądów gospodarczych. Czynnik czwarty w sposób wyraźny dotyczy alienacji politycznej. $W$ dalszych partiach tekstu czynnik pierwszy określać będę jako czyn-

\begin{tabular}{|c|c|c|c|c|}
\hline & \multicolumn{4}{|c|}{ Sktadouta } \\
\hline & 1 & 2 & 3 & 4 \\
\hline yn|zm & .782 & & & \\
\hline Ulegosic & .681 & & & \\
\hline $\begin{array}{l}\text { negatywna ocena } \\
\text { crtowieka }\end{array}$ & 542 & & & .333 \\
\hline punitywizm & .521 & & & \\
\hline autarytaryzm & 486 & & & \\
\hline saquacentryzm & & & & \\
\hline tradycjonalizm mo ralrí & & -.786 & & \\
\hline tradycjonalizm seksualny & & -.776 & & \\
\hline patriotyzm & & -.736 & & \\
\hline etrocentryzm & .489 & -.589 & & \\
\hline akceptacja prywatyzacji & & & 828 & \\
\hline sodalistycziny resentyrment & & & -.670 & \\
\hline $\begin{array}{l}\text { niechéc do kapitalu } \\
\text { zagranicznego }\end{array}$ & & &,- 563 & \\
\hline $\begin{array}{l}\text { akceptacja Iróznicoubania } \\
\text { spoteczrego }\end{array}$ & .420 & & 547 & \\
\hline $\begin{array}{l}\text { interwh encjonizn } \\
\text { spoteczro-gospodarczy }\end{array}$ & & & -.388 & .337 \\
\hline palityczna bezsilnasc & & & & .773 \\
\hline palitycze wy abcow'anie & & & & .740 \\
\hline
\end{tabular}

Metada wyadręaniania czynników - Gtównych składawych. Wetoda rotacji - Oblimin z normalizacja Kaisera. Rotacja osiagnneta żieżnosć w 12 iteraqjach. nik negatywnej percepcji rzeczywistości społecznej (w skrócie NPRS); drugi jako konserwatyzm (K), trzeci jako liberalne postawy gospodarcze (LPG), czwarty zaś jako polityczną alienację (PA) ${ }^{8}$.

Wszystkie cztery czynniki pozostają ze soba skorelowane. Współczynniki korelacji r Pearsona (por. Tabela 5) wskazuja, iż najsilniej związane pozostają ze sobą PA oraz NPRS (związek dodatni) oraz PA oraz LPG (związek ujemny), nieco słabiej PA oraz K (zwiazzek o charakterze ujemnym). Innymi słowy, im wyższy poziom negatywnej oce-

\begin{tabular}{|c|c|c|c|c|}
\hline & NPRB & $K_{i} i-?$ & LPG & PA \\
\hline NPRS & 1 & $-1030^{* * *}$ & $-.085 i^{*}$ & $245 i^{* * *}$ \\
\hline$K_{2}(-i$ & $-.103 t^{* *}$ & 1 & $.162\left(\left.\right|^{* *}\right\}$ & $-.143(t *)$ \\
\hline LPG & $-, 0850^{*}:$ & $162(* *)$ & -1 & $-.221(+*)$ \\
\hline $\mathrm{PA}_{\mathrm{A}}$ & $.2450^{* * i}$ & $-143\left(^{* *}\right)$ & $\left.-.221{ }^{* *}\right\}$ & 1 \\
\hline
\end{tabular}
ny rzeczywistości spolecznej, konserwatyzmu oraz niższy poziom liberalizmu gospodarczego tym wyższy poziom politycznej alienacji. Negatywna percepcja rzeczywistości społecznej do-

miejsca nie pozwala na ukazanie w tym artykule metodologicznych walorów i wad ww. narzędzi badawczych.

${ }^{8}$ Po identyfikacji i interpretacji czynników szacowano metodą regresyjną wartości czynnikowe, które stały się podstawą dalszych analiz. 
datnio związana jest $\mathrm{z}$ konserwatyzmem oraz liberalnymi postawami gospodarczymi. Z kolei liberalne poglądy na gospodarkę są ujemnie skorelowane są z konserwatyzmem.

Centralność Postawy Religijnej (CPR) najmocniej związana jest z konserwatyzmem (K). Współczynnik korelacji r Persona (por. Tabela 6) wskazuje, iż im wyższy poziom CPR, tym wyższy poziom K. CPR koreluje również z liberalnymi postawami gospodarczymi (LPG - związek o charakterze ujemnym) oraz dodatnio z polityczną alienacja (PA). Przy czym, dwie ostatnie zależności sa zależnościami o stosunkowo slabej sile. Brak jest (statystycznie istotnego)

\begin{tabular}{|c|c|}
\hline & $\mathrm{CPR}$ \\
\hline tradycjonalizm moralny' & $.482(* \pi)$ \\
\hline tradycjonalizm seksualmy' & $.5\left[14 !^{* * *}\right)$ \\
\hline patriotyzm & $331\left({ }^{*}\right)$ \\
\hline etrocentryzm & $.2377^{* * *}$ \\
\hline
\end{tabular}
związku liniowego między CPR a negatywną percepcją rzeczywistości społecznej (NPRS). Generalnie, im wyższy poziom religijności, tym wyższy poziom konserwatyzmu, niższy liberalizm gospodarczy oraz wyższy poziom politycznej alienacji. Do podobnych wniosków prowadzi analiza współczynników standaryzowanych beta wielokrotnej regresji liniowej (metoda krokowa), wskazujących (por. Tabela 7) iż zdecydowanie najsilniejszy związek zachodzi między CPR a postawami konserwatywnymi, wyraźnie mniejszy jest on w przypadku negatywnej percepcji rzeczywistości spolecznej oraz politycznej alienacji.

Uchwycenie jedynie korelacji między CPR a

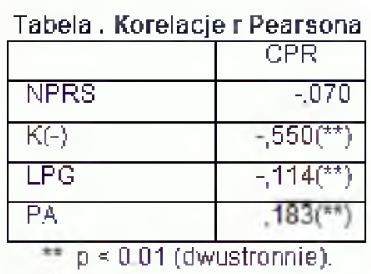

* $p=0.05$ ["dwitustrannie) zmiennymi syntetycznymi utworzonymi w wyniku zastosowania analizy czynnikowej nie pozwala wniknąć $w$ istotę poznanych zależności. $W$ celu pogłębienia wiedzy na temat wyróżnionych postaw społecznych konieczne jest podjęcie analizy na poziomie samych indeksów bazowych wchodzących w skład poszczególnych składowych glównych. Temu zagadnieniu poświęcony zostanie poniższy fragment artykułu.

\begin{tabular}{|c|c|c|c|c|}
\hline lulodel & & $\begin{array}{l}\text { Wrspotcynniki } \\
\text { standaryzowane }\end{array}$ & $t$ & Istotnasc \\
\hline & & Beta & & \\
\hline \multirow[t]{4}{*}{3} & (Stala) & & .000 & 1.000 \\
\hline & $K(-)$ & -.546 & -16.691 & .000 \\
\hline & TPRES & -162 & $-4,841$ & .000 \\
\hline & PA & 144 & 4.289 & गणए। \\
\hline
\end{tabular}

Spośród pięciu indeksów tworzących czynnik NPRS centralność postawy religijnej koreluje jedynie (por. Tabela 8) z dwoma: ujemnie $\mathrm{z}$ cynizmem oraz dodatnio $\mathrm{z}$ autorytaryzmem. Im wyższy poziom religijności, tym niższy poziom cynizmu oraz wyższy poziom autorytaryzmu. Wysoki poziom postaw religijnych niesie więc 
ze sobą dwie wzajemnie znoszące się - w kontekście negatywnej percepcji rzeczywistości spolecznej - konsekwencje. Z jednej strony przyczynia się do niwe-

\begin{tabular}{|c|c|}
\hline & CPR \\
\hline CyחIITI & $-199\left({ }^{* *}\right)$ \\
\hline Uleghosí & 009 \\
\hline $\begin{array}{l}\text { negatywna ocena } \\
\text { crotowieka }\end{array}$ &,- 029 \\
\hline punitywizm &, 022 \\
\hline autorytaryzun & $112 \Gamma^{2+*}$ \\
\hline
\end{tabular}
lowania instrumentalnego podejścia do ludzi (a więc do pomniejszania NPRS), $z$ drugiej wiąże się podwyższonym poziomem postaw autorytarnych (a więc powiększa NPRS). Przy braku związku liniowego $\mathrm{z}$ pozostałymi elementami wchodzacymi $\mathrm{w}$ skład tego czynnika zrozumiały staje brak statystycznie istotnego związku między CPR a NPRS.

Znacznie prostsza sytuacja występuje w przypadku zwiazku CPR z postawami konserwatywnymi. W przypadku wszystkich indeksów tworzących ten czynnik zauważyć bowiem można zachodzenie dodatniej korelacji między nimi a CPR (por. Tabela 9). Im wyższy poziom religijnośći, tym wyższy poziom tradycjonalizmu moralnego, seksualnego, patriotyzmu oraz etnocentryzmu.

Stosunkowo klarowna jest również sytuacja w przypadku czynnika postaw gospodarczych. W tym przypadku CPR koreluje z trzema indeksami: niechęcią wobec kapitału zagranicznego, interwencjonizmem społeczno-gospodarczym oraz akceptacja prywatyzacji (por. Tabela 10 ). Im wyższy poziom CPR, tym większa niechęć wobec kapitału zagranicznego, wyższy poziom oczekiwań na interwencjonizm państwa w sferze społecznogospodarczej oraz niższy poziom akceptacji prywatyzacji. Na tym tle jasny staje się ujemny zwiazek zachodzacy między czynni-

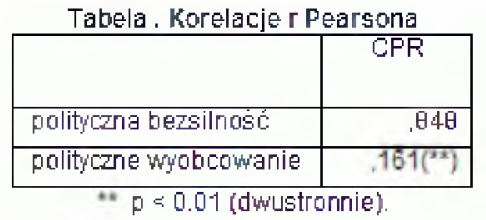
kiem liberalnych postaw gospodarczych a poziomem centralności postawy reli-

Tabela, Korelacje r Pearsona

\begin{tabular}{|c|c|}
\hline & $\mathrm{CPF}$ \\
\hline riechéc do kapitału zagranicznego & $2180^{+t}$ \\
\hline sodjalistycziy' resenty/rient & -.042 \\
\hline interhtencjonizm spot-lgospodarczy' & $\left.2290^{* *}\right)$ \\
\hline akceptcja zðóżnicondania spod & -.045 \\
\hline akceptacja prywatyzacji & -7001 \\
\hline
\end{tabular}
gijnej. Religijność okazuje się więc czynnikiem sprzyjającym raczej socjalnym niż liberalnym rozwiazaniom ekonomicznym.

Ciekawsza sytuacja rysuje się w przypadku politycznej alienacji (por Tabela 11). Spośród dwóch składajacych się nań indeksów CPR koreluje tylko z jednym: politycznym wyobcowaniem, a więc $\mathrm{z}$ niemożnościq integracji czy identyfikacji z rzeczywistościq społeczno-politycznq (Korzeniowski, 1999: 63). Brak jest z kolei związków między poziomem religijności a polityczną bezsilnością. Biorąc pod uwagę dodatni związek lączący PA oraz K postawić można hipotezę, iż polityczna alie- 
nacja osób o wysokim poziomie CPR wynikać może nie tyle z niemożności percepcyjnego ogarnięcia zjawisk politycznych ( $\mathrm{z}$ winy ograniczonych możliwości poznawczych podmiotu), lecz z niezgody na funkcjonowanie ladu w sposób, w jaki on funkcjonuje ( $\mathrm{z}$ winy percypowanych odchyleń od normy przedmiotu). Niemożność „zrozumienia” ładu politycznego bylaby tu konsekwencja jego negatywnej oceny kształtującej się w kontekście wartości moralnych oraz narodowych.

Tabela. Whyiki analizy regresji

\begin{tabular}{|c|c|c|c|c|}
\hline lodel & & $\begin{array}{c}\text { Wrspóccynniki } \\
\text { standaryzowane }\end{array}$ & t & istotrosc \\
\hline & & Beta & & \\
\hline \multirow[t]{8}{*}{7} & (Stara) & & .000 & -1.000 \\
\hline & tradycjonalizm sekGualny' & 296 & 7.297 & 000 \\
\hline & tradýcjonalizm moralny' & .211 & 5.223 & 000 \\
\hline & cynizm & -.141 & $-4,30-1$ &, 000 \\
\hline & $\begin{array}{l}\text { interhericjonizrn } \\
\text { spoteczno-gospod arczy }\end{array}$ & 103 & 2,807 & .005 \\
\hline & patriotyzm & 109 & 3.106 & .002 \\
\hline & $\begin{array}{l}\text { sogalistycz'y' } \\
\text { resentyment }\end{array}$ & -103 & $-2,985$ & .0103 \\
\hline & $\begin{array}{l}\text { niechéc do kapitał। } \\
\text { zagranicuego }\end{array}$ & .086 & 2,403 & .017 \\
\hline
\end{tabular}

a Zmienıa zależก: CPR

Analiza wielokrotnej regresji liniowej (metodą krokowa) wskazuje, iż spośród wszystkich 14. indeksów wprowadzonych do równania siedem w sposób statystycznie istotny wiąze się z centralnością postawy religijnej (por. Tabela 12). Sa to (w porządku malejącym): tradycjonalizm seksualny, tradycjonalizm moralny, cynizm (związek o charakterze ujemnym), interwencjonizm społecznogospodarczy, patriotyzm, socjalistyczny resentyment (związek o znaku ujemnym) oraz niechęć wobec kapitału zagranicznego. Potwierdzenie znajduje więc teza, iż wpływ religijności na orientacje społeczno-polityczne uwidacznia się przede wszystkim w ich wymiarze moralnym. 


\section{Orientacje na osi prawica-lewica a poziom centralności postawy religijnej}

Związek zachodzacy między CPR a postawami konserwatywnymi wskazuje, iż centralność postawy religijnej powinna wiązać się raczej z prawicowymi niż lewicowymi orientacjami politycznymi. W celu weryfikacji tego przypuszczenia umożliwiono badanym samookreślenie swoich sympatii politycznych na osi: prawica-centrum-lewica. Pytanie brzmialo: Program, której orientacji politycznej jest najbliższy P/P przekonaniom? Ankietowany mógł wskazać jedną z podanych możliwości odpowiedzi: zdecydowanie prawicowy, prawicowy, centroprawicowy, centrowy, centro-lewicowy, lewicowy, zdecydowanie lewicowy. Respondent mógł wskazać także odpowiedź: żaden.

Pod względem położenia na osi sympatii ideowych (lewicaprawica) wśród badanych zaobserwować można niemal doskonala symetrię. Osób deklarujących sympatie centroprawicowe jest niemal tyle samo, co osób uważajacych swoje poglądy za centrolewicowe $(16,2 \%$ i $16,8 \%)$, sympatyków postaw prawicowych niemal tyle samo, co lewicowych $(23,5 \%$ oraz $22,4 \%$ ). Jedynie zwolenników poglądów zdecydowanie prawicowych jest nieco więcej niż zdecy-

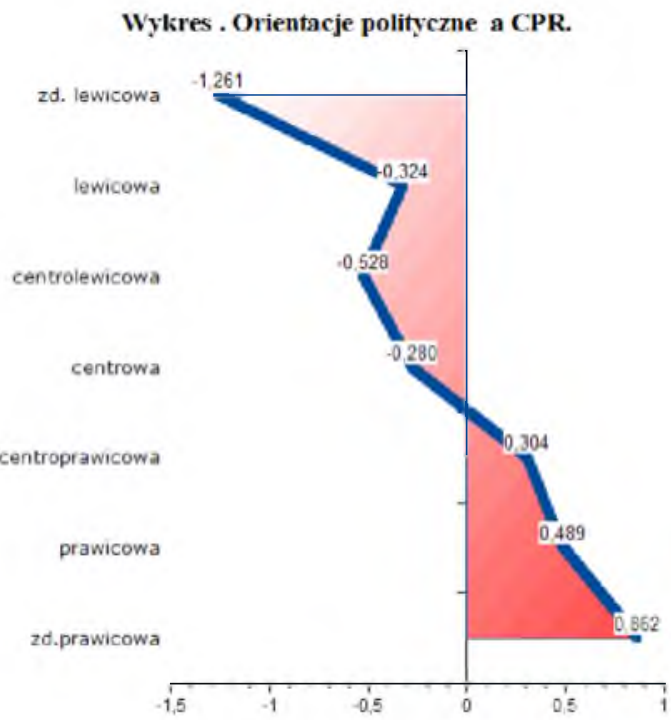
dowanie lewicowych $(8,2 \%$ wobec $3,4 \%)$. Sympatycy poglądów centrowych stanowią jedynie 9,5\% spośród badanych.

W celu sprawdzenia związku zachodzącego między postawami religijnymi a autodeklaracjami dotyczącymi położenia na osi prawica-lewica zastosowano jednoczynnikową analizę wariancji (ANOVA). Poziom istotności testu $F$ $\left(p<0,001\right.$, przy $F=19,539, d f=6$ oraz $\left.\eta^{2}=0,23\right)$ wskazuje na zachodzenie statystycznie istotnych różnic między średnimi CPR według kategorii autodeklaracji ideowych. Analiza średnich (por. Wykres 3) wskazuje na niemal liniowy charakter zwiazku lączącego obie zmienne. Im bardziej prawicowe postawy autodeklaracje ideowe, tym wyższy poziom CPR. Tak więc centralność postawy religijnej okazuje się zjawiskiem stosunkowo mocno związanym $z$ deklaracjami 
polityczno-ideowymi. W tym kontekście szczególnie interesujące wydaje się prześledzenie związku między religijnością a sympatiami partyjnymi $z$ jednej strony oraz preferencjami wyborczymi z drugiej.

\section{CPR a sympatie partyjne i preferencje wyborcze}

Narzędzie do pomiaru sympatii partyjnych składało się z listy 7 organizacji politycznych (głównie partii politycznych) oraz skali służącej do wyrażenia przez badanych własnych postaw wobec nich. Ostatecznie lista objęła: SLD, UP, PSL, Samoobrona, PO, PiS, oraz LPR. Ankietowanych poproszono o odpowiedź, w jakim stopniu dana organizacja budzi ich sympatię (lub niechęć). Badani posługiwali się siedmiostopniową skalą: od zdecydowanie nie podoba mi się do zdecydowanie podoba mi się.

Zdecydowanie najwyższym poziomem (por. tabela nr 13) sympatii cieszy

\begin{tabular}{|c|c|c|c|c|}
\hline & sympiatia & obojętriasić & niechec & Ogótem \\
\hline $\begin{array}{l}\text { Sojusz Lewicy } \\
\text { Demokratycunej }\end{array}$ & $26,2 \%$ & $34,7 \%$ & $39,1 \%$ & $100,0 \%$ \\
\hline Unia Pracy' & $18.6 \%$ & 47,95 & 33,5 喘 & $100,0 \%$ \\
\hline $\begin{array}{l}\text { Platforma } \\
\text { Obyywatelska }\end{array}$ & $23,6 \%$ & $46,9 \%$ & $29.5 \mathrm{~m}$ & $100,0 \%$ \\
\hline $\begin{array}{l}\text { Prawo i } \\
\text { Sprawiedliwost }\end{array}$ & 37,5 啘 & 41.1 品 & 21,5 富 & $100,0 \%$ \\
\hline $\begin{array}{l}\text { Palskie Strannictwo } \\
\text { Ludowe }\end{array}$ & $21.0 \%$ & $51,5 \%$ & $276 \mathrm{~b}$ & $100,0 \%$ \\
\hline Samoobrana & $16.0 \%$ & $30,4 \mathrm{~m}$ & 53.6 踏 & $100,0 \%$ \\
\hline Liga Polskich Rodzin & $22,6 \%$ & $37,6 \%$ & $39.4 \mathrm{~d}$ & $100,0 \%$ \\
\hline
\end{tabular}

Prawo i Sprawiedliwość $(37,5 \%)$. Nieco mniejszy poziom sympatii odnotowaly: Sojusz Lewicy Demokratycznej $(26,2 \%)$, Platforma Obywatelska $(23,6 \%)$, Polskie Stronnictwo Ludowe (21\%) oraz Liga Polskich Rodzin $(22,8 \%)$. Wyraźnie najmniejszą sympatię budzi Unia Pracy $(18,6 \%)$ oraz Samoobrona (16\%). Największy potencjalny elektorat „negatywny” (mierzony wskaźnikiem osób deklarujących brak sympatii) odnotowano w przypadku Samoobrony $(53,6 \%)$, nieco mniejszy w przypadku SLD $(39,1 \%)$ oraz Unii Pracy $(33,5 \%)$. Przeprowadzone badania potwierdzaja więc dominacje prawicowo-konserwatywnych sympatii politycznych wśród mieszkańców regionu.

Dla ustalenia związków zachodzących między CPR a sympatiami partyjnymi posłużono się macierza niepodobieństwa (na bazie odległości euklidesowej). Przedstawione w Tabeli 14 dane wskazuja, iż najmniejsza odległość (którą można interpretować jako stopień okazywanej sympatii) dzieli CPR od LPR. Nieco dalej znajduje się PiS oraz Samoobrona. Osoby o wysokim poziomie CPR odczuwaja $\mathrm{z}$ Tabela . Macierz niepodobienstwa (przeskalowana odległość euklidesowa)

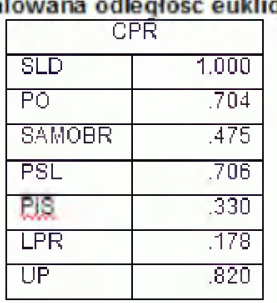
kolei wyraźną niechęć wobec PO, UP oraz SLD. 
Wykres . Wyniki skalowania wielowymiarowego.

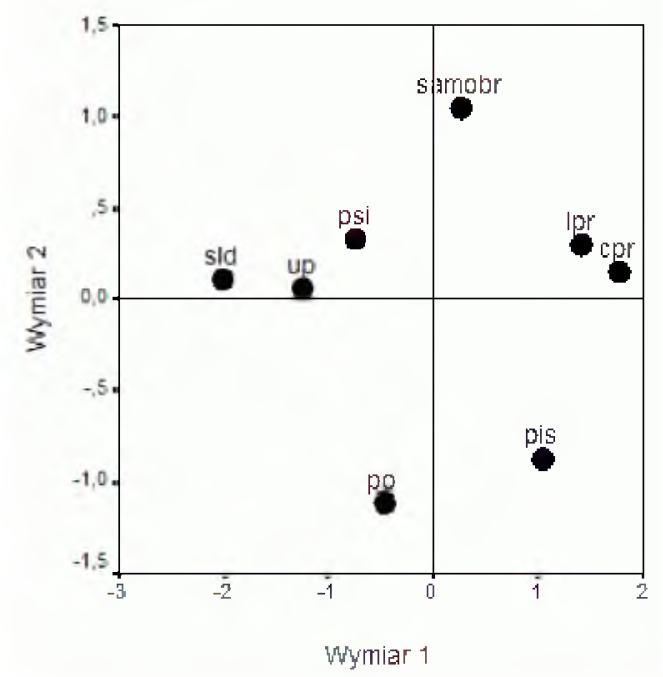

Dla wizualizacji związków występujących między CPR a sympatiami wobec poszczególnych partii politycznych wykorzystano skalowanie wielowymiarowe (por Wykres 4). Wymiar pierwszy wskazuje na odleglość poszczególnych ugrupowań politycznych od CPR (im wyższy wynik na osi $X$, tym bliższy związek określonego ugrupowania $z \mathrm{CPR})$.

Nieco inny sposób zastosowano do określenia preferencji wyborczych ankietowanych. W tym przypadku wykorzystano stosowana przez Sopocką Pracow-

nię Badań Społecznych - metodę subiektywnego prawdopodobieństwa oddania głosu na określone ugrupowanie polityczne w najbliższych wyborach parlamentarnych (Pieńkowski, Krzykowski 1995). Badanych poproszono o rozdzielenie puli 100 procent pomiędzy kilka największych partii, określając w ten sposób szanse głosowania na każdą z nich ${ }^{10}$.

W celu uchwycenia związków zachodzących między CPR a sympatiami partyjnymi posłużono się macierzą niepodobieństwa (na bazie odległości euklidesowej - por. Tabela 15). Podobnie jak było to w przypadku sympatii partyjnych, także $w$ odniesieniu do preferencji wyborczych zauważyć można ścisły związek lączący CPR z LPR oraz PiS. Nieco

Tabela , Macierz niepodobiénstwa [przeskalowana odległośc euklides owa)

\begin{tabular}{|l|l|}
\hline \multicolumn{2}{|c|}{ CPR } \\
\hline SLD+UP & .991 \\
\hline PSL & .517 \\
\hline PO & .599 \\
\hline LPR & .0010 \\
\hline BS & .159 \\
\hline SAMOER & .377 \\
\hline
\end{tabular}

słabszy jest on w przypadku Samoobrony. Wyraźnie mało prawdopodobne jest oddanie głosu przez osoby o wysokim poziomie CPR na PSL oraz PO. Odległość

\footnotetext{
${ }^{9}$ Niezbędne obliczenia wykonano bazując na przygotowanej wcześniej macierzy niepodobieństwa. Dwa wymiary wyodrębniono w trzech iteracjach. Współczynnik Stress wyniósł 0,14 , RSQ zaś 0,93.

${ }^{10}$ Uwzględniono te partie, których szanse na wyborczy sukces wydawały się w okresie badań znaczne.
} 
między CPR a koalicją SLD i UP jest zdecydowanie największa. Wizualizację odległości poszczególnych ugrupowań politycznych od CPR zawiera Wykres $5^{11}$.

Przedstawiony uklad związków między preferencjami wyborczymi a poziomem centralności postawy religijnej nakazuje postawić pytanie, jakie wartości spoleczne, moralne i gospodarcze powoduja istnienie takich a nie innych sympatii i antypatii politycznych. Innymi słowy, jakie uklady wartości leżą u

Wykres . Wyniki skalowania wielowymiarowego.

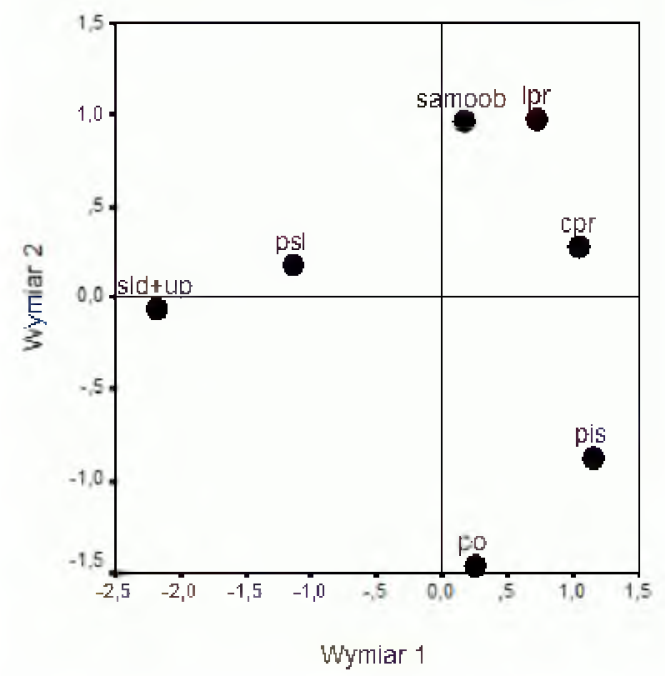
podstaw określonych sympatii politycznych wiążących się z wysokim poziomem CPR? Dla odpowiedzi na to pytanie posłużono się analizą kanoniczną wprowadzając do analiz wszystkie indeksy wartości, jakimi posługiwano się $w$ trakcie badań oraz indeks CPR wraz z deklaracjami dotyczącymi prawdopodobieństwa oddania glosu na określone ugrupowanie polityczne. Niestety, z powodu ograniczonej objętości niniejszego artykułu zmuszony jestem zrezygnować ze szczególowego przedstawienia warstwy statystycznej dokonanych analiz. Ograniczę się jedynie do wskazania głównych wniosków z

nich płynących i to tylko w odniesieniu do głównych partii lokalnej sceny politycznej.

W przypadku CPR oraz preferowania SLD czynnikami nade wszystko różnicującymi oba zjawiska okazują się tradycjonalizm seksualny, tradycjonalizm moralny oraz patriotyzm. Im wyższy poziom tradycjonalizmu moralnego, seksualnego oraz patriotyzmu, tym wyższy poziom CPR oraz niższy poziom poparcia dla SLD. Identyczny układ wartości odnotowano w przypadku pary CPR i PiS, przy czym w tym przypadku znaki ladunków wskazują nie tyle na różnice, co podobieństwo. Inaczej mówiąc, tradycjonalizm seksualny, tradycjonalizm moralny, patriotyzm są tymi właśnie wartościami, dzięki którym religijność łączy się z poparciem dla PiS. Podobny stan rzeczy odnotowano w przypadku pary CPR i LPR. Przy czym, oba zjawiska lączy także etnocentryzm oraz

11 Przedstawia on partie polityczne oraz CPR w ukladzie dwóch wymiarów powstałych w efekcie zastosowania skalowania wielowymiarowego $\mathrm{w}$ oparciu o macierz niepodobieństwa (Stress $=0,16, \mathrm{RSQ}=0,82$, wymiary wyodrębniono w czterech iteracjach). 
niechęć wobec kapitału zagranicznego (które nie występowały w przypadku par CPR-SLD oraz CPR-PiS). Tak więc, tym co w LPR „cenne” dla osób religijnych to system wartości moralno-narodowych o konserwatywnym zabarwieniu.

Podobny układ wartości fundujący związek CPR z PiS oraz LPR każe postawić pytanie, jakie orientacje różnicują oba elektoraty. Przeprowadzone obliczenia wskazuja, iż czynnikami sprzyjającymi preferowaniu PiS, odrzucaniu LPR i zachowywaniu przeciętnego poziomu CPR są: niski poziom sentymentu wobec socjalizmu, niski poziom niechęci wobec kapitału zagranicznego oraz pozytywny stosunek wobec prywatyzacji. Tak więc elektorat PiS przy podobnym poziomie religijności, a co za tym idzie podobnym systemie wartości (konserwatywno-patriotycznych) jest jednocześnie znacznie bardziej liberalny pod względem gospodarczym. Wizualizacje odległości wybranych ugrupowań politycznych od CPR oraz ważniej-

$$
\text { Whkres . Wyniki shalgwania wielowymiarowego. }
$$

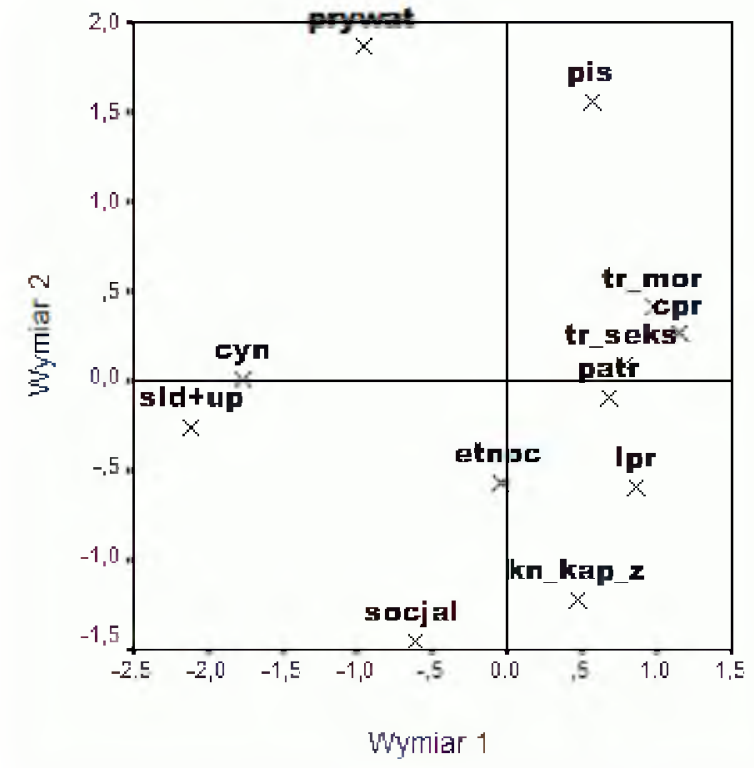
szych (w kontekście analizy kanonicznej) wartości przedstawia Wykres 6 powstały na podstawie skalowania wielowymiarowego w oparciu o macierz niepodobieństwa ${ }^{12}$.

\section{CPR a udział w wyborach i formy aktywności politycznej}

W referowanych badaniach jako wskaźnik przyjęto deklaracje badanych dotyczące udziału w trzech ostatnich wyborach (prezydenckich, parlamentarnych oraz samorządowych). Za brak udziału ankietowany otrzymywał 0 punktów, za udział 1 punkt. W efekcie indeks aktywności wyborczej (AW) zawierał się w przedziale od 0 do 3 punktów. Średnia utworzonego w ten spoób indeksu wyniosła 2,1 (co świadczy o stosunkowo znacznej aktywności wyborczej badanych), zaś współczynnik zgodności wewnętrznej $\alpha$ Cronbacha równy był 0,81.

\footnotetext{
${ }^{12}$ Stress $=0,18, \mathrm{RSQ}=0,83$, wymiary wyodrębniono w czterech iterakcjach.
} 
Dla sprawdzenia związku zachodzącego między aktywnością wyborczą a CPR zastosowano jednoczynnikową analizę wariancji (ANOVA). Przed przystapieniem do obliczeń dokonano kategoryzacji zmiennej CPR na pięć mniej więcej równolicznych grup, w ten sposób iż grupa pierwsza objęla osoby o najniższym poziomie CPR, zaś grupa piąta osoby o najwyższym poziomie CPR (grupa 1 punkt podziału 20 percentyl; grupa 2 - 40 percentyl; grupa 3 - 60 percentyl; grupa 4 - 80 percentyl).

Analiza wariancji wskazuje na zachodzenie statystycznie istotnego związku między CPR a AW $(\mathrm{p}<0,001, \quad$ przy $\mathrm{F}=6,319$ i $\mathrm{df}=4)$. Jednocześnie współczynnik $\eta^{2}$ wskazuje, iż tylko $3,8 \%$ wariancji zmiennej niezależnej wyjaśniane jest przez różne poziomy $\mathrm{CPR}$. Analiza średnich wskazuje na niemal doskonale liniowa

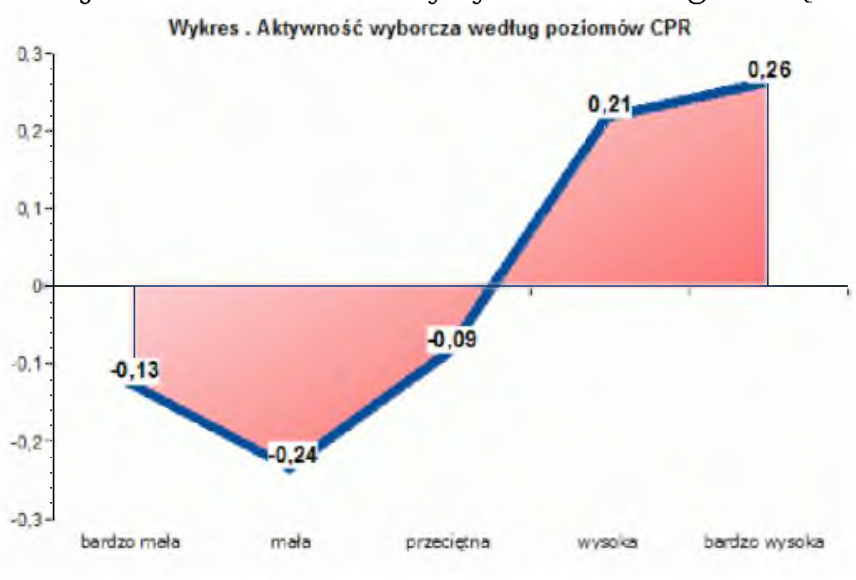
zależność między oby zmiennymi (por. Wykres 7). Im wyższy poziom CPR, tym częstszy udział w wyborach o charakterze politycznym. Również współczynnik korelacji r Pearsona wskazuje na istnienie związku między AW i nieskategoryzowaną CPR $(\mathrm{r}=0,140$, przy $\mathrm{p}<0,001)$. Dodatnia wartość tego współczynnika dowodzi, iż wraz ze wzrostem poziomu religijności rośnie jednocześnie wyborcza aktywność.

W kontekście występującego związku między obu zmiennymi problemem wartym zainteresowania wydaje się być określenie czynników prowadzacych do istnienia tej zależności, a więc odpowiedź na pytanie, dlaczego w zasadzie reli-

\begin{tabular}{|c|c|c|c|c|}
\hline $\begin{array}{l}\text { Mod } \\
\text { el }\end{array}$ & & $\begin{array}{l}\text { WSpatczynniki } \\
\text { standaryo whane }\end{array}$ & $\mathrm{t}$ & Istatnosé \\
\hline & & Beta & & \\
\hline \multirow[t]{6}{*}{5} & (Stała) & & .000 & 1.000 \\
\hline & cynizm & -.153 & $-3,849$ & 000 \\
\hline & patriotyen & 127 & 3,247 &, 001 \\
\hline & niechęc do kapitału zagr. & -.039 & $-2,497$ & 013 \\
\hline & punitywiचm & 106 & 2,606 & .009 \\
\hline & politycrna bersilnasć & -.083 & $-2,050$ & 041 \\
\hline
\end{tabular}

niowej metoda krokową (por. Tabela 16). Jej wyniki wskazuja iż spośród wszystkich 17 . indeksów pięć w sposób wyraźny wplywa na AW: cynizm, pa-

gijność wpływa na poziom aktywności wyborczej, jakie orientacje wiążą się zarówno $\mathrm{z}$ reli gijnościa, jak frekwencja wyborczą? Do tego celu posłużono się analizą Wielokrotnej regresji li-
niki wskazuja, iż spośród 
triotyzm, niechęć do kapitału zagranicznego, punitywizm oraz polityczna bezsilność.

W czasie wcześniejszych analiz stwierdzono już występowanie związków liniowych między CPR a tradycjonalizmem seksualnym, tradycjonalizmem moralnym, cynizmem, interwencjonizmem spoleczno-gospodarczym, patriotyzmem, socjalistycznym resentymentem oraz niechęcią wobec kapitału zagranicznego (por. Tabela), a więc zbliżonym (choć nie tożsamym) układem zmiennych. W następnym kroku analiz kontrolowano (przy pomocy współczynnika korelacji cząstkowej Pearsona) różne konfiguracje zmiennych pochodzących z obu zbiorów testując jednocześnie zmiany współczynnika korelacji $r$ Pearsona między CPR a AW. W efekcie ustalono (por. Tabela 17), iż statystycznie istotny związek między CPR a AW zanika przy kontrolowanym wpływie patriotyzmu, tradycjonalizmu seksualnego oraz cynizmu. Czynnikami pośredniczącymi pomiędzy religijnością a aktywnością wyborczą są więc wartości moralne związane z etyką seksualną oraz społeczna,

a także wartości podstawowe, związane $\mathrm{z}$ pozytywnym wartościowaniem własnej przynależności narodowej. O ile związek między religijnością a patriotyzmem i nieinstrumentalną etyką społeczną nie wymaga dalszych komentarzy, o tyle interesujace jest dlaczego ele-

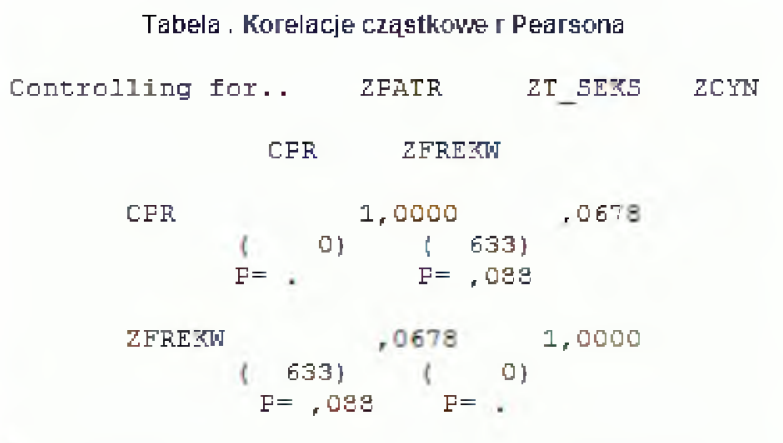

(Coefficient / (D.F.) / 2-teiled Significance) mentem pośredniczącym okazuje się także tradycjonalizm seksualny.

Dla głębszego zrozumienia relacji między analizowanymi zmiennymi przeprowadzono analizę ścieżkową (por Wykres 8 ) $^{13}$. Na jej podstawie stwierdzić można, iż tradycjonalizm seksualny w ukladzie analizowanych zmiennych w sposób znaczący wzmacnia patriotyzm. Tak więc wpływ tej zmiennej na AW jest nie tylko bezpośredni, lecz także pośredni - odbywa się również poprzez ksztaltowanie patriotyzmu.

${ }^{13}$ Chi kwadrat=5,506; $\mathrm{df}=2, \mathrm{p}=, 064 ;$ AGFI=994, GFI=997; RMSEA=0,049. 


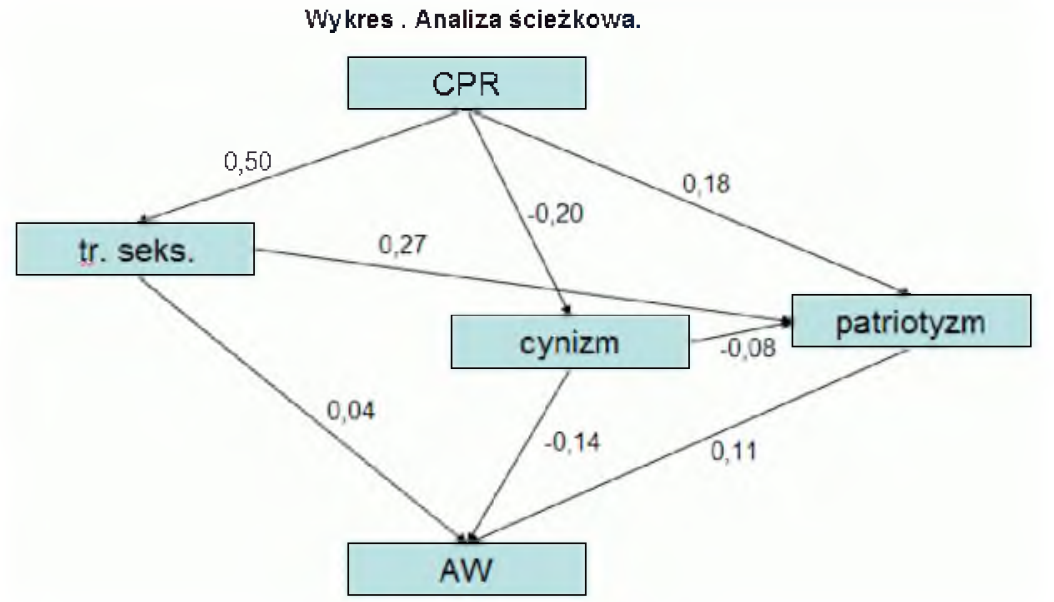

Generalnie stwierdzić więc można, iż wplyw religijności na aktywność wyborczą realizuje się poprzez kształtowanie postaw związanych z: (1) absolutyzmem moralnym, którego jednym z ważniejszych wymiarów jest konieczność ścisłego przestrzegania norm moralnych (nawet tych, które bywaja relatywizowane przez większość społeczeństwa w praktyce życia - jak ma to miejsce $\mathrm{w}$ przypadku sfery seksualnej) tak w życiu prywatnym, jak i spolecznym oraz (2) pozytywnym wartościowaniem własnego kraju (patriotyzmem). Jednocześnie pobudzony przez religijność absolutyzm moralny staje się dodatkowym (obok samej religijności) czynnikiem wpływającym na kształtowanie się orientacji patriotycznej. Etyka w kontekście religijności nie jest więc etyką ograniczającą się do spraw indywidualnych, subiektywnych, obejmuje także sferę szeroko rozumianych zjawisk społecznych (także politycznych).

Aktywność wyborcza jest rzecz jasna ważnym, lecz tylko jedną z form, jakie przybierać może aktywność polityczna obywateli. W kontekście zauważonych sympatii partyjnych interesujące wydaje się określenie tego, z jakiego formami aktywności politycznej wiążą się postawy religijne. Dla uchwycenia preferowanych przez ankietowanych form działalności politycznej postawiono następujące pytanie: Jakie działania uznałby Pan/Pani za dopuszczalne dla obrony swoich praw, gdyby zostały one naruszone? Badani mieli za zadanie ustosunkować się do 13. różnych form działalności politycznej, które - w założeniu - reprezentowały dwa odrębne typy działań politycznych: standardowe oraz radykalne na siedmiopunktowej skali: od zdecydowanie nie do zdecydowanie tak. 
W celu zweryfikowania trafności założeń, co do charakteru poszczególnych zmiennych zastosowano analizę czynnikowa metodą składowych głównych $\mathrm{z}$ rotacja Varimax (por. Tabela 18$)^{14}$. Zgodnie $\mathrm{z}$ przewidywaniami skladowa pierwsza odnosiła się do radykalnych form aktywności politycznej, druga zaś do

Tabela . Whniki analizy czynnikowej.

\begin{tabular}{|c|c|c|}
\hline & \multicolumn{2}{|c|}{ Component } \\
\hline & -1 & 2 \\
\hline Okup ow anie budynkónt ùytec:nosci publicznej & .834 & \\
\hline Udzał wielegalnych strajkach & .804 & \\
\hline Udział wielegalnych zgromadzeniach i demonstracjach & .792 & \\
\hline Grozienie wybutaniem strajky & .736 & \\
\hline Elokowhanie dróg. mostón etc. & .716 & \\
\hline Udzat wh strajkach ghodowych & .705 & \\
\hline 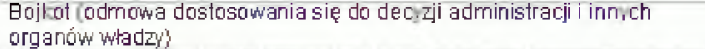 &, 700 & \\
\hline Pikietowanie pred budynkami administracji lub inngch arganow wadzi & .563 & .442 \\
\hline Interwe niowarie u posłow, radnych, eto. & & .788 \\
\hline Udzat wh spotkaniach i zebrariach a charaktere politycen ym & & .723 \\
\hline Zbierarie podpisow pod petycjami polity cznymi & & 692 \\
\hline Udzat wh legalnych demonstracjach politycanych & & 668 \\
\hline Aktyowy udziat uw kampanii whtiorczej & & .641 \\
\hline
\end{tabular}

form typu standardowego.

Współczynnik korelacji r Pearsona wskazuje na występowanie liniowej zależności jedynie $w$ przypadku centralności postawy religijnej i

standardowych formami aktywności politycznej $(\mathrm{r}=0,037$ przy $\mathrm{p}<0,05)$. Im wyższy poziom CPR, tym wyższy poziom standardowych form aktywności politycznej. Między radykalnymi formami politycznej aktywności brak jest statystycznie istotnych związków o charakterze liniowym $(\mathrm{p}>0,05)$.

Dokonana w podobny sposób, jak miało to miejsce w przypadku aktywności wyborczej analiza regresji wielokrotnej metodą krokową wskazuje, iż spośród 14. wprowadzonych do równania zmiennych sześć wiąże się $\mathrm{z}$ aktywnością polityczną w sposób statystycznie istotny: autorytaryzm (ujemnie), cynizm (ujemnie), polityczna bezsilność (również ujemnie), tradycjonalizm moralny, akceptacja zróżnicowania społecznego oraz socjalistyczny resentyment (por. Tabela 19).

\begin{tabular}{|c|c|c|c|c|}
\hline PWodel & & $\begin{array}{c}\text { Whepótcynniki } \\
\text { standaryzowan } \\
\text { e }\end{array}$ & $\mathrm{t}$ & Istotrasć \\
\hline & & Eeta & & \\
\hline \multirow[t]{7}{*}{6} & [Stała! & & .010 & 1.000 \\
\hline & autorytaryzm & -228 & $-5,274$ & .000 \\
\hline & cynizm & -165 & $-4,144$ & 000 \\
\hline & polityczra bezsinnosc & -155 & $-3,825$ & .000 \\
\hline & tradycjonalizm moralny' & 129 & 3.400 & .007 \\
\hline & $\begin{array}{l}\text { akceptcja zoznicobania } \\
\text { spotecznego }\end{array}$ & .119 & 3,058 & .002 \\
\hline & socjalistycziy' resentyment & 193 & 2,755 & .006 \\
\hline
\end{tabular}

${ }^{14}$ Miara KMO wyniosła 0,885, poziom istotności testu sferyczności Bartletta był niższy niż 0,001 (przy 78 stopniach swobody oraz chi kwadrat równym 3517,34 ). 


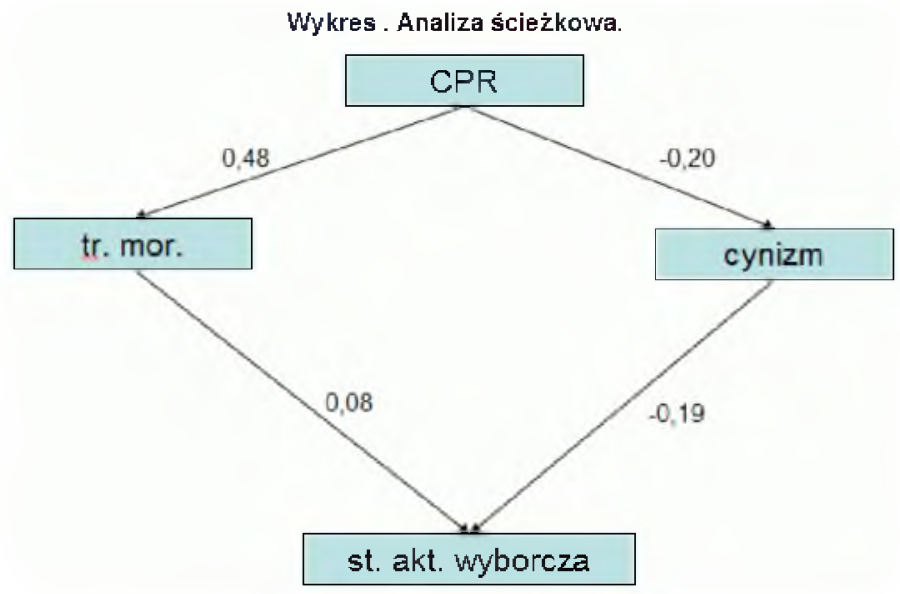

Także w tym przypadku poszukiwano czynników pośredniczących między centralnością postawy religijnej a aktywnością polityczną. Dokonane analizy wskazują, iż statystycznie istotny związek między CPR a aktywnością polityczną zanika przy kontrolowanym wplywie tradycjonalizmu moralnego oraz cynizmu $(\mathrm{r}=0,0181$, przy $\mathrm{p}=649)$. Tak więc również $\mathrm{w}$ tym przypadku wiążące się $\mathrm{z}$ religijnościa przekonania moralne mają zasadniczy wpływ na kształtowanie określonych postaw politycznych. Dla wzmocnienia postawionej tezy przeprowadzono analizę ścieżkową (por Wykres 9) ${ }^{15}$.

\section{Wnioski}

Celem prowadzonych $\mathrm{w}$ niniejszym artykule analiz było prześledzenie związku łączącego postawy religijne $\mathrm{z}$ szeroko pojętymi orientacjami politycznymi: orientacjami na wartości i interesy (jako podstawowymi wyznacznikami ideologii politycznej), orientacjami ideowymi na osi prawica-lewica, sympatiami partyjnymi, preferencjami wyborczymi, frekwencja wyborcza oraz preferowanymi formami aktywności politycznej.

\footnotetext{
${ }^{15}$ Chi kwadrat=3,948; $\mathrm{df}=2, \mathrm{p}=0,139$; AGFI=985, GFI=997; RMSEA $=0,039$.
} 
Na podstawie przeprowadzonych badań stwierdzić można, iż religijność (mierzona za pomocą narzędzia CPR) zajmuje istotne miejsce w świadomości większości badanych - jest raczej centralnym niż peryferyjnym elementem struktury osobowej. Jest ona zwiazana nade wszystko ze sposobem socjalizacji wskazuje na to związek poziomu CPR przede wszystkim z płcią oraz pochodzeniem społecznym). Utrzymująca się stabilność struktury społecznej w Polsce wskazuje, iż poziom życia religijnego nie powinien w najbliższym okresie ulegać większym wahaniom (pod warunkiem - rzecz jasna - braku zmiany modeli wychowawczych).

Spośród szeregu orientacji moralnych, społecznych, politycznych i gospodarczych centralność postawy religijnej wiąże się przede wszystkim z konserwatyzmem społeczno-moralnym (pozytywny związek między CPR a tradycjonalizmem moralnym, seksualnym, patriotyzmem oraz etnocentryzmem). W mniejszym stopniu związana jest $\mathrm{z}$ anty-liberalnymi postawami gospodarczymi oraz alienacją polityczną.

Religijność wyraźnie sprzyja przyjmowaniu prawicowej identyfikacji na osi prawica-lewica. Konsekwencją tego faktu jest wyraźna sympatia okazywana przez badanych o wysokim poziomie CPR ugrupowaniom typu LPR oraz PiS (choć także Samoobrony) oraz wyraźną niechęcią żywioną w stosunku do UP oraz (nade wszystko SLD).

Badając układy wartości leżące u podstaw określonych sympatii i antypatii politycznych stwierdzono, iż osią w zasadniczy sposób różnicującą preferencje polityczne ankietowanych pozostają nie tyle interesy, co sfera wartości (nade wszystko konserwatyzm społeczno-moralny). Zreferowane badania potwierdzaja wyniki wcześniejszych analiz (Grygiel, Grzesik, 2002), świadczących o tym, że współczesne społeczeństwo Podkarpacia (a przynajmniej mieszkańców Rzeszowa) charakteryzuje specyficzny typ podziału socjopolitycznego, który określić można jako aksjologiczny (por. Schoppflin, 1990, 1993; Herbut, 1998). Zinterpretowane dane wskazuja, że od orientacji gospodarczych istotniejszą rolę w kreowaniu sceny politycznej odgrywaja postawy wobec wartości (narodowych, religijnych czy moralnych). One właśnie generują niechęć prawicy wobec lewicy, a więc decydują o polaryzacji sceny politycznej ${ }^{16}$.

\footnotetext{
${ }^{16}$ Wspomniany wyżej G. S c h o p f 1 in sugerowal, że okres komunizmu przyczynił się do zamrożenia tradycyjnych wartości i przekonań, które ujawniły się z nową siłą w próżni powstałej po upadku autorytarnego porządku. Potwierdza to słowa M. Z i ółk ow sk i e go, że w polskiej rzeczywistości olbrzymią rolę odgrywają działania będące przejawem orientacji receptywnoroszczeniowej (Ziólkowski, 2001), dążącej do utrzymania określonych rozwiazań realnego socjalizmu (Ziółkowski, 1999). W ten sposób przeszłość objawia się jako wprawdzie politycznie pokonana, lecz społecznie nieprzezwyciężona.
} 
Postawy religijne wiążą się również z aktywnością polityczną tj. aktywnością wyborczą oraz standardowo pojmowaną działalnością polityczną. Przyczyną istnienia tego związku jest $\mathrm{z}$ jednej strony ksztaltowanie przez religię postaw wspólnotowych (przede wszystkim patriotyzmu) oraz określonych postaw moralnych (niskiego poziomu cynizmu, wysokiego poziomu tradycjonalizmu moralnego opartego na świadomości nie-relatywnego charakteru wartości i norm). Oddziaływanie tego typu orientacji aksjologicznych nie ogranicza się jedynie do sfery życia prywatnego, lecz wkracza także w sferę publiczną. Tak więc stwierdzić można, iż religijność sprzyja kształtowaniu się normatywnego sposobu ujmowania rzeczywistości społeczno-politycznej. W perspektywie śsiadomości religijnej życie polityczne nie jest pojmowane jako wolna gra sił rozmaitych interesów, lecz obowiązek obywatelski związany z dobrem wspólnoty narodowej.

\section{Literatura}

Achen, Ch. H. (1975). Mass political attitudes and the survey response. American Political Science Review 69: 1218-1231.

Budge, I. (1994). A new spatial theory of party competition: uncertainty, ideology and policy equilibria viewed comparatively and temporally. British Journal of Political Science 24: 443-467.

Grygiel P., Grzesik A. (2002). Wartości i interesy. Spoleczny wymiar orientacji politycznych. W: Społeczeństwo Podkarpacia na przełomie wieków, red. M. Malikowski, Rzeszów: Mana.

Herbut R. (1998), Systemy partyjne krajów Europy Centralnej i Wschodniej oraz wzorce rywalizacji politycznej, w: Demokracje Europy Środkowo-Wschodniej w perspektywie porównawczej, red. A. Antoszewski, R. Herbut, Wrocław: Wyd. Uwr.

Inglehart R, and Klingemann H-D (1976). Party identification, ideological preference and the left-right dimension among Western mass publics. In Ian Budge, Ivor Crewe, and Dennis Farlie (eds.), Party Identification and Beyond: Representations of Voting and Party Competition. London: John Wiley \& Sons.

Jacoby W. G. (1995). The structure of ideological thinking in the American electorate. American Journal of Political Science 39: 314-335.

Laver M., and Budge I. (1993). Party Policy and Coalition Government in Western Europe. London: Macmillan.

Lijphart, A. (1984). Democracies: Patterns of Majoritarian and Consensus Government in Twenty One Countries. New Haven: Yale University Press.

MacRae, D. (1958). Dimensions of Congressional Voting. Berkeley: University of California Press. 
Mahler, Gregory S (1995). Comparative Politics: An Institutional and CrossNational Approach. Englewood Cliffs, NJ: Prentice Hall.

Nie, N. H., Verba S., and Petrocik, John R. (1976). The Changing American Voter.

Pieńkowski R., Krzykowski G. (1995), Zastosowanie subiektywnych prawdopodobieństw do pomiaru preferencji wyborczych, Kolokwia Psychologiczne t.4 7382.

Poole, K. and Rosenthal H. (1997). Congress: A Political-Economic History of Roll Call Voting. New York: Oxford University Press.

Przybylski K (1996). Politologia. Zarys problematyki. Katowice: Wyd. Śląsk.

Schopflin G. (1990), The Prospects for Democracy in Central and Eastern Europe, w: Uncertain Futures: Eastern Europe and Democracy, New York: IEWWS.

Volkens A. (1995). Dataset CMPr3, Comparative Manifestos Project. Science Center Berlin, Research Unit Institutions and Social Change (Director HansDieter Klingemann) in cooperation with the Manifesto Research Group (Chairman Ian Budge).

Weisberg H. F. and Rusk J. 1970. Dimensions of Candidate Evaluation. American Political Science Review 64 (December): 1167-85.

Wesolowski W1. (1997). Aktorzy sceny politycznej i demokracja, w: Pierwsza sześciolatka 1989-1995. Próba bilansu polityki, red. M. Grabowska, S. Mocka: Warszawa: ISP PAN.

Wesołowski Wl. (1999). Typy więzi społecznych a przejście od komunizmu do demokracji. Role więzi wspólnotowych, stowarzyszeniowych i komunitarnych, w: Indywidualizm a kolektywizm, red. A. Morstin, Warszawa: IFiS PAN.

Wojtaszczyk K.A. (1998). Partie polityczne w państwie demokratycznym. Warszawa: Wyd. Szkolne i Pedagogiczne.

Ziółkowski M. (1999). Interesy i wartości jako elementy świadomości społecznej, w: Władza i struktura spoleczna. Księga dedykowana Włodzimierzowi Wesolowskiemu, red. A. Jasińska-Kania, K.M. Stomczyński, Warszawa: IFIS PAN. Ziółkowski M. (2001). Mentalność i strategie przystosowawcze społeczeństwa polskiego w latach 1988-1998, w: Rozumienie zmian społecznych, red. E. Hałas, Lublin: TN KUL.

Żukowski T. (2003). Jacy są wyborcy prawicy. „Międzynarodowy Przegląd Polityczny" 1/2003 37-64. 